\title{
Genotype $\times$ Environment effects on morphological and productive components of sweet potato (Ipomoea batatas L.)
}

Sindi Elen Senff, Viviane de Fátima Milcheski, Ana Caroline Basniak Konkol, Ana Carolina da Costa Lara Fioreze

Universidade Federal de Santa Catarina - UFSC, Centro de Ciências Rurais, Curitibanos, SC. E-mail: ana.lara@ufsc.br.

\begin{abstract}
Sweet potato (Ipomoea batatas L.) is a crop with high market demands because of its well-known health benefits. Limited use of improved clones reduces the crop's income potential. Plant breeding programs seek to select genotypes with good results in a variety of environments by evaluating the interaction effects of genotypes and environments. This study aimed to assess Clone $\times$ Growing season effects on morphological and productive parameters of sweet potato clones grown in the municipality of Curitibanos, Santa Catarina, Brazil, in 2016/2017 and 2017/2018. The following clones were evaluated: Brazlândia Rosada, BRS Amélia, Beauregard, Brazlândia Roxa, and BRS Rubissol. A randomized block design with three replications was used to investigate root length, root diameter, mean root weight, total root number, number of marketable roots, total yield, and marketable yield. Data were subjected to one-way and twoway analysis of variance. Beauregard afforded the largest number of marketable roots and was stable in both growing seasons. Beauregard, Brazlândia Roxa, and Brazlândia Rosada differed in total number of roots between growing seasons. There were no significant differences between growing seasons in mean root weight; BRS Amélia afforded a higher mean root weight than Brazlândia Rosada. Beauregard did not differ in total or marketable yield between growing seasons and provided higher yields than the other clones. BRS Rubissol and Beauregard were found to be the most promising for sweet potato cultivation under the environmental conditions of Curitibanos.
\end{abstract}

Keywords: clones; stable; roots; marketable yield.

Interação genótipos $\mathrm{x}$ ambientes em componentes morfológicos e produtivos de batata-doce (Ipomoea batatas L.)

\section{RESUMO}

A batata-doce (Ipomoea batatas L.) é uma cultura de alta demanda pelo mercado consumidor, devido aos estudos que comprovamos seus benefícios à saúde. Contudo, o baixo uso de clones melhorados reduz a lucratividade potencial da cultura. O melhoramento de plantas busca selecionar genótipos com bons resultados em uma gama de ambientes através da avaliação da presença de interação genótipos $\mathrm{x}$ ambientes. A partir disso, objetivou-se avaliar a presença de interação clones $\mathrm{x}$ safras em caracteres morfológicos e produtivos de clones de batata-doce, no município de Curitibanos- SC, nas safras de 2016/2017 e 2017/2018. Os clones avaliados foram Brazlândia Rosada, BRS Amélia, Beauregard, Brazlândia Roxa e BRS Rubissol. O delineamento experimental utilizado foi de blocos casualizados com três repetições. Foram realizadas as avaliações das raízes tuberosas: comprimento (CR), diâmetro (DR), massa média (MMR), número total (NTR), número de raízes comerciais (NRC), produção total (PT) e produção comercial (PC). Os dados foram submetidos à análise de variância individual e conjunta. O clone Beauregard se destacou por apresentar o maior número de raízes comerciais e por ser estável em diferentes ambientes. Beauregard, Brazlândia Roxa e Brazlândia Rosada apresentaram diferença entre safras para o número total de raízes. Não houve diferenças significativas entre safras para a massa média de raízes, notando a superioridade de BRS Amélia sobre Brazlândia Rosada. O clone Beauregard não apresentou comportamento diferencial entre safras tanto para a produtividade comercial e total, e foi destaque em 
comparação com os outros clones. Os clones BRS Rubissol e o Beauregard foram considerados os mais promissores para o cultivo de batata-doce nas condições de Curitibanos/SC.

Palavras-chave: clones; estável; raízes; produtividade comercial.

\section{Introduction}

Stimulated by the need for rustic, highenergy foods, sweet potato (Ipomoea batatas L.) cultivation is carried out in more than 100 countries, most of which are developing countries (SILVA et al., 2008). The widespread distribution of this species stemmed from its high adaptability to different climates and soils and resistance to pests and diseases (TANAKA et al., 2017). This tuberous root is the vegetable with the lowest production cost worldwide (SILVA et al., 2008). Since the discovery of the healthpromoting effects of sweet potato, several countries have focused on improving the species to stimulate the development of derived products (YOSHIMOTO, 2010).

Given the high demands of the new consumer market, Brazil has focused on genetic improvement programs for sweet potato. Although there are 30 genotypes registered in the Brazilian Ministry of Agriculture, Livestock, and Food Supply (BRASIL, 2020), many farmers still use nonimproved genotypes, resulting in low national production levels (CAVALCANTE et al., 2009). According to IBGE (2020), the mean crop yield in Brazil is $14.06 \mathrm{t} \mathrm{ha}^{-1}$, considered low in comparison with those of other countries, such as Japan $\left(22.31 \mathrm{t} \mathrm{ha}^{-1}\right)$, China $\left(22.38 \mathrm{t} \mathrm{ha}^{-1}\right)$, Australia (36.42 $\mathrm{t} \mathrm{ha}^{-1}$ ), and Senegal (40.41 t $\left.\mathrm{ha}^{-1}\right)$. Thus, breeding programs are important for the development of improved genotypes (LEAL et al., 2021), which may contribute to increasing the average national production.

After a genotype is developed, genetic improvement programs will provide specific recommendations based on the evaluation of crop performance in different environments. With this information, farmers may choose the clone with the best productive performance and quality for a given location and growing season. For this, it is necessary to quantify Genotype $\times$ Environment effects, allowing the assessment of production stability, adaptability to specific environments, and genetic contribution to the observed phenotype (CRUZ et al., 2012). For sweet potato crops, it is particularly important to investigate production stability over growing seasons, as genotypes will be used unlimitedly through multiplication or vegetative propagation, carried out by the farmers themselves.

This study aimed to estimate the interaction effects of sweet potato clones and growing seasons in order to select superior genotypes adapted to different regions.

\section{Materials and Methods}

Experiments assessing different clones of sweet potato were conducted in the Agricultural Experimental Area of the Federal University of Santa Catarina $\left(27^{\circ} 16^{\prime} \mathrm{S} 50^{\circ} 30^{\prime} \mathrm{W}\right)$, Curitibanos, Santa Catarina State, Brazil, during the 2016/2017 and 2017/2018 growing seasons. The climate is temperate with mild summers (Cfb type), and the soil is a Haplic Cambisol of clayey texture (550 $\mathrm{g} \mathrm{kg}^{-1}$ clay) (EMBRAPA, 2018).

Sweet potato clones were kindly donated by Embrapa Canoinhas and multiplied in Irineópolis, Santa Catarina State, during two seasons. Five clones were evaluated: Brazlândia Rosada, BRS Amélia, Beauregard, Brazlândia Roxa, and BRS Rubissol. These clones differ in skin and pulp color, shape, and root size (Table 1). The experimental design used in the two growing seasons was a randomized block design with five treatments and three replications. Each experimental unit consisted of four rows spaced $0.75 \mathrm{~m}$ apart. Each row measured $1.10 \mathrm{~m}$ in length and was planted with four plants at $0.30 \mathrm{~m}$ intervals, totaling 16 plants per plot. The eight central plants were considered as the useful plot area. Plots were tilled using a rotary hoe and received a basal application of $0.5 \mathrm{t} \mathrm{ha}^{-1}$ NPK (933-12) fertilizer with incorporation. Planting was performed manually. Plants were manually irrigated until the emergence of the first shoots. Weed management was carried out manually at 30 days after planting of the first crop and 23 days after planting of the second crop. 
Table 1. Characteristics of sweet potato clones used in the study.

\begin{tabular}{|c|c|c|c|c|}
\hline Clone & $\begin{array}{l}\text { Place of } \\
\text { collection }\end{array}$ & Characteristics & Cycle (days) & Advantages \\
\hline $\begin{array}{l}\text { Brazlândia } \\
\text { Rosada }\end{array}$ & $\begin{array}{c}\text { Brazlândia, } \\
\text { Federal District, } \\
\text { Brazil }\end{array}$ & $\begin{array}{l}\text { Pink skin, elongated shape, } \\
\text { and light-colored pulp }\end{array}$ & 150 & Good commercial traits \\
\hline Beaureard & $\begin{array}{l}\text { Louisiana, United } \\
\text { States of America }\end{array}$ & $\begin{array}{l}\text { Elongated, uniform roots, } \\
\text { purplish-red skin, and } \\
\text { smooth surface }\end{array}$ & $120-140$ & $\begin{array}{l}10 \text { times higher } \\
\text { carotenoid content }\end{array}$ \\
\hline BRS Amélia & $\begin{array}{l}\text { São Lourenço do } \\
\text { Sul, Rio Grande } \\
\text { do Sul, Brazil }\end{array}$ & $\begin{array}{l}\text { Pink skin. After cooking or } \\
\text { roasting, it becomes moist } \\
\text { and creamy with a soft and } \\
\text { extremely sweet taste. }\end{array}$ & $120-140$ & $\begin{array}{c}\text { Rich in provitamin A. Skin } \\
\text { can be easily separated } \\
\text { from the pulp. }\end{array}$ \\
\hline $\begin{array}{l}\text { Brazlândia } \\
\text { Roxa }\end{array}$ & $\begin{array}{l}\text { Brazlândia, } \\
\text { Federal District, } \\
\text { Brazil }\end{array}$ & $\begin{array}{l}\text { Purple skin. Cream-colored } \\
\text { pulp that turns yellowish } \\
\text { when cooked. Very dry, with } \\
\text { low fiber content. }\end{array}$ & 150 & $\begin{array}{l}\text { Highly resistant to soil } \\
\text { pests }\end{array}$ \\
\hline $\begin{array}{c}\text { BRS } \\
\text { Rubissol }\end{array}$ & $\begin{array}{c}\text { Pelotas, Rio } \\
\text { Grande do Sul, } \\
\text { Brazil }\end{array}$ & $\begin{array}{l}\text { The pulp is cream-colored or } \\
\text { yellowish and has a floury } \\
\text { texture after cooking or } \\
\text { roasting. }\end{array}$ & $120-150$ & High yield \\
\hline
\end{tabular}

Temperature (average, maximum, and minimum) and rainfall data were collected and analyzed for the two growing seasons, starting from the day of planting. Values are presented as weekly means (Figures 1 and 2).

Figure 1. Weekly weather data for the 2016/2017 growing season. Curitibanos, Santa Catarina, Brazil. Source: UFSC (2016), UFSC (2017).

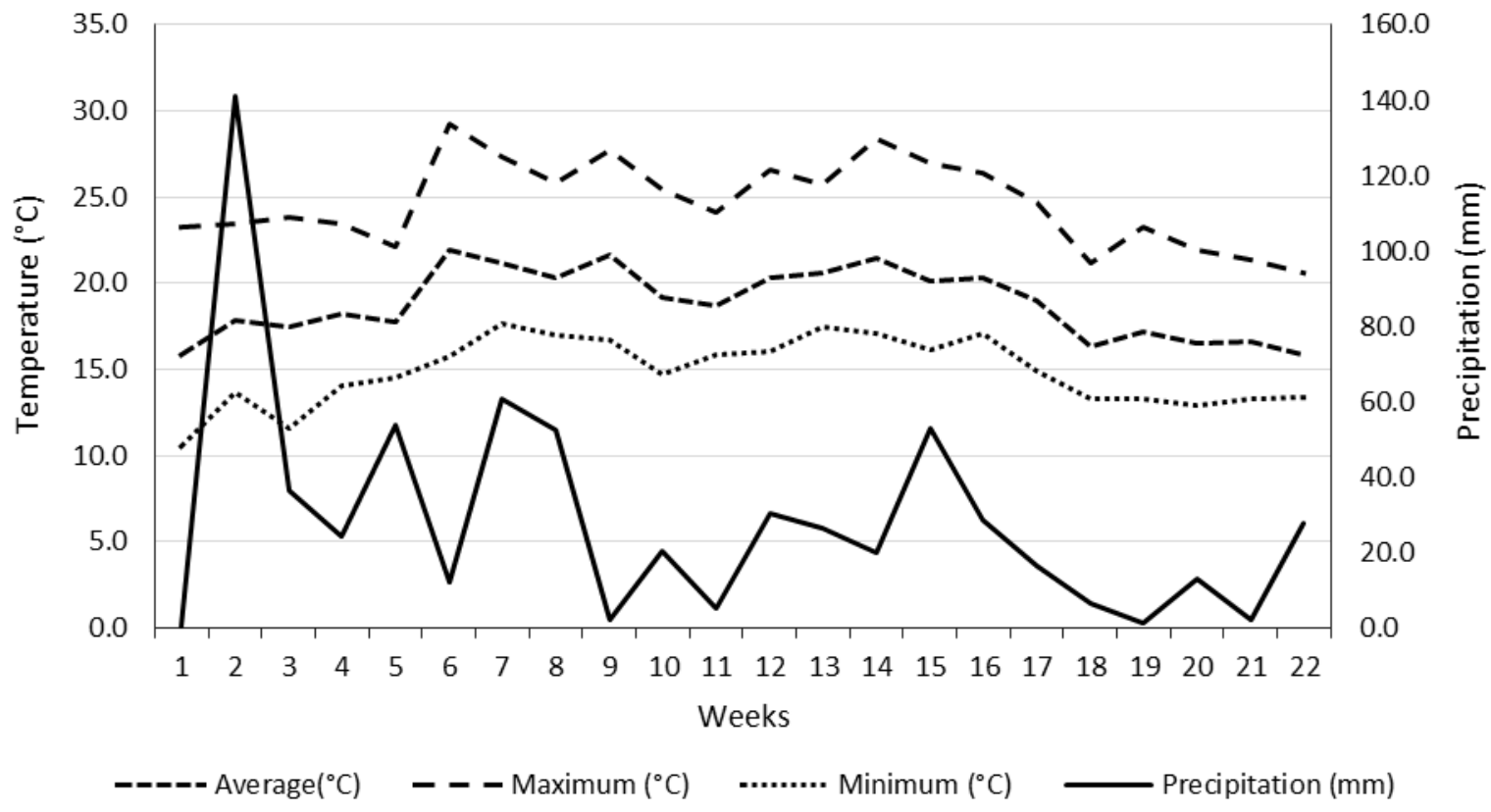


Figure 2. Weekly weather data for the 2017/2018 growing season. Curitibanos, Santa Catarina, Brazil. Source: UFSC (2017), UFSC (2018).

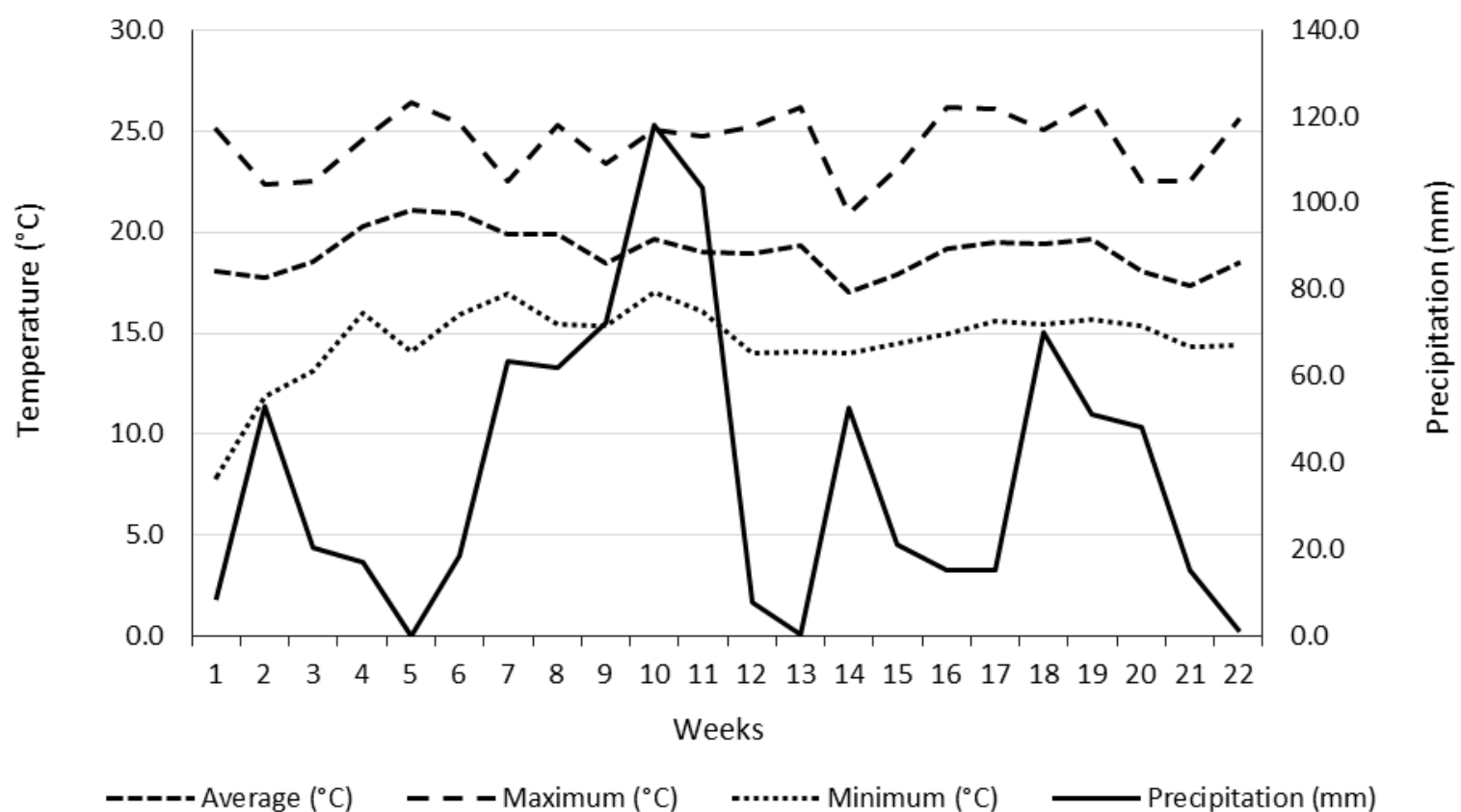

In the fifth month of each crop cycle, plants were harvested and their roots collected for analysis. Root length $(\mathrm{cm})$ was measured along the longitudinal axis by using a graduated ruler. Root diameter $(\mathrm{mm})$ was determined transversally at the middle section by using a digital caliper. The mean root weight $(\mathrm{g})$ was calculated as the total root weight divided by the number of roots per plot. The total root number was determined as the total number of roots collected from each useful plot area. The number of marketable roots was determined by counting all roots weighing between 100 and $800 \mathrm{~g}$ per useful plot area. Total yield $\left(\mathrm{t} \mathrm{ha}^{-1}\right)$ was calculated as the weight of all roots collected from each useful plot and converted from kilograms per square meter to tonnes per hectare. Marketable yield $\left(\mathrm{t} \mathrm{ha}^{-1}\right)$ was determined as the weight of all marketable roots collected from each useful plot and converted to tonnes per hectare.

Quantitative data for each growing season were subjected to one-way analysis of variance by the $F$-test $(p<0.05)$ using GENES software (CRUZ, 2001). After verification of the homogeneity of residual mean squares $(<7)$, data were subjected to two-way analysis of variance by the $F$-test $(p<0.05)$. Means were compared using Tukey's test $(p<0.05)$. Expected mean squares were used to estimate the heritability coefficient of each trait.

\section{Results and Discussion}

Analysis of variance revealed significant interaction effects of clones and growing seasons on marketable root number, total root number, root diameter, mean root weight, total yield, and marketable yield (Table 2). Clones differed in productive parameters between growing seasons, precluding comparison of means, which could only be performed for root length, as the parameter was not influenced by interaction effects.

The mean heritability values for the two growing seasons are presented in Table 2. Total root number and mean root weight had low heritability ( 0.08 and 0.14 , respectively), given the great influence of the environment on these traits. Total and marketable yields, on the other hand, had high heritability values, demonstrating the high accuracy of selection for these traits. These findings are important, because total and marketable yields are crucial for the selection and recommendation of sweet potato clones. 
Table 2. Mean squares for the traits of sweet potato clones in the 2016/2017 and 2017/2018 growing seasons. Curitibanos, Santa Catarina, Brazil.

\begin{tabular}{|c|c|c|c|c|}
\hline Source of variation & $\mathbf{R L}$ & RD & MRN & TRN \\
\hline Block & 8.8 & 25.6 & 31.0 & 366.7 \\
\hline Growing season & $17.9 *$ & $177.8^{*}$ & $653.3^{*}$ & $5740.8^{*}$ \\
\hline Clone & $25.2^{*}$ & $546.4^{*}$ & $185.2^{*}$ & $314.1^{*}$ \\
\hline Growing season $\times$ Clone & $6.09^{\mathrm{ns}}$ & $165.6^{*}$ & $85.9 *$ & $286.9^{*}$ \\
\hline Error & 4.0 & 18.1 & 11.1 & 69.2 \\
\hline CV (\%) & 22 & 11.9 & 20.5 & 28 \\
\hline Heritability & 0.75 & 0.69 & 0.53 & 0.08 \\
\hline Source of variation & MRW & \multicolumn{2}{|c|}{ TY } & MY \\
\hline Block & 2684.6 & \multicolumn{2}{|c|}{551.5} & $235.6^{*}$ \\
\hline Growing season & 1415.0* & \multicolumn{2}{|c|}{$6295.3^{*}$} & $2002.5^{*}$ \\
\hline Clone & 9143.0* & \multicolumn{2}{|c|}{ 1830.6* } & $647.7^{*}$ \\
\hline Growing season $\times$ Clone & 7853.3* & \multicolumn{2}{|c|}{$463.4^{*}$} & $244.0^{*}$ \\
\hline Error & 2950.6 & \multicolumn{2}{|c|}{114.7} & 68.0 \\
\hline CV (\%) & 17.7 & \multicolumn{2}{|c|}{21.0} & 25.3 \\
\hline Heritability & 0.14 & \multicolumn{2}{|c|}{0.74} & 0.62 \\
\hline
\end{tabular}

$\mathrm{RL}$, root length; RD, root diameter; MRN, marketable root number; TRN, total root number; MRW, mean root weight; $\mathrm{TY}$, total yield; $\mathrm{MY}$, marketable yield.

*Significant at $p<0.05$.

The unfolding of Clone $\times$ Growing season interaction effects on productive parameters is described in Table 3. Beauregard, BRS Rubissol, Brazlândia Roxa, and Brazlândia Rosada differed significantly in marketable root number between growing seasons. Beauregard stood out among the other clones for having the highest marketable root numbers in both 2016/2017 and $2017 / 2018$. Similar results were reported by Silva et al. (2015) in Canoinhas, Santa Catarina State, in 2012 and 2013, further confirming the stability of the clone in different environments. The authors also observed that BRS Amélia had a low variation in marketable root number between growing seasons, allowing to infer that the clone is stable with regard to marketable root number.

Total root number differed between growing seasons in Beauregard, Brazlândia Roxa, and Brazlândia Rosada. In 2017/2018, these clones afforded a higher number of total roots than BRS Amélia (Table 3). Although the clones achieved optimal performance in the 2017/2018 season, an even higher performance was reported by Melo et al. (2020) in Brasília, Federal District. The total root number of Beauregard, Brazlândia Roxa, and Brazlândia Rosada in the referred study was 252,343 , and $156 \%$ higher, respectively, than that observed in the current study in the second season. Amaro et al. (2019), in evaluating eight genotypes in Umbaúba, Sergipe, also obtained higher total root numbers with Beauregard, Brazlândia Rosada, and BRS Rubissol. As reported by the authors, Brazlândia Roxa achieved a similar total root number (52.75) in the 2014 season as that observed in the present study (Table 3).

No differences in mean root weight were observed between growing seasons. The parameter was higher in BRS Amélia than in Brazlândia Rosada (Table 3). In the study of Silva et al. (2015), BRS Amélia achieved outstanding values, with $540 \mathrm{~g}$ and $560 \mathrm{~g}$ in 2012 and 2013, respectively. Nevertheless, in the referred study, the clone was considered the least productive. Beauregard, Brazlândia Roxa, and BRS Rubissol afforded higher mean root weights in the study of Silva et al. (2015) than in the current study. The mean root weight of BRS Amélia and BRS Rubissol in 2017 was similar to that reported by Amaro et al. (2017). Massaroto et al. (2014) observed higher values: $224.8 \mathrm{~g}$ in Brazlânda Roxa and $276.8 \mathrm{~g}$ in Brazlânda Rosada. 
Table 3. Interaction effects of Clone $\times$ Growing season on sweet potato traits. Curitibanos, Santa Catarina, Brazil.

\begin{tabular}{|c|c|c|c|c|}
\hline \multirow{2}{*}{ Clone } & \multicolumn{2}{|c|}{ MRN } & \multicolumn{2}{|c|}{ TRN } \\
\hline & 2016/2017 & $2017 / 2018$ & $2016 / 2017$ & $2017 / 2018$ \\
\hline Beauregard & $14.33 \mathrm{Ba}$ & $36.00 \mathrm{Aa}$ & $15.67 \mathrm{Ba}$ & $56.00 \mathrm{Aa}$ \\
\hline BRS Rubissol & $9.33 \mathrm{Bb}$ & $17.67 \mathrm{Ab}$ & $13.67 \mathrm{Aa}$ & 35.67 Aab \\
\hline Brazlândia Roxa & 13.67 Bab & $18.33 \mathrm{Ab}$ & $23.00 \mathrm{Ba}$ & $54.33 \mathrm{Aa}$ \\
\hline BRS Amélia & $11.00 \mathrm{Aab}$ & $13.00 \mathrm{Ab}$ & $20.33 \mathrm{Aa}$ & $25.33 \mathrm{Ab}$ \\
\hline Brazlândia Rosada & $6.00 \mathrm{Bb}$ & $19.67 \mathrm{Ab}$ & $12.33 \mathrm{Ba}$ & $46.33 \mathrm{Aa}$ \\
\hline \multirow{2}{*}{ Clone } & \multicolumn{2}{|c|}{$\mathrm{RD}(\mathrm{mm})$} & \multicolumn{2}{|c|}{ MRW (g) } \\
\hline & $2016 / 2017$ & $2017 / 2018$ & $2016 / 2017$ & $2017 / 2018$ \\
\hline Beauregard & $62.57 \mathrm{Aa}$ & $62.45 \mathrm{Ab}$ & $384.55 \mathrm{Aa}$ & $311.08 \mathrm{Aab}$ \\
\hline BRS Amélia & 56.14Bab & $79.31 \mathrm{Aa}$ & $303.88 \mathrm{Aa}$ & 891.73Aa \\
\hline Brazlândia Rosada & $47.72 \mathrm{Ab}$ & $47.52 \mathrm{Ac}$ & $306.94 \mathrm{Aa}$ & 216. 33Ab \\
\hline BRS Rubissol & $47.72 \mathrm{Ab}$ & $56.15 \mathrm{Abc}$ & $290.33 \mathrm{Aa}$ & 277.80 Aab \\
\hline Brazlândia Roxa & $46.72 \mathrm{Ab}$ & $44.12 \mathrm{Ad}$ & $283.52 \mathrm{Aa}$ & $303.60 \mathrm{Aab}$ \\
\hline \multirow{2}{*}{ Clone } & \multicolumn{2}{|c|}{$M Y\left(t h^{-1}\right)$} & \multicolumn{2}{|c|}{$\operatorname{TY}\left(\mathrm{t} \mathrm{ha}^{-1}\right)$} \\
\hline & $2016 / 2017$ & $2017 / 2018$ & $2016 / 2017$ & $2017 / 2018$ \\
\hline Beauregard & $35.01 \mathrm{Aa}$ & $36.31 \mathrm{Ab}$ & $65.24 \mathrm{Aa}$ & $77.43 \mathrm{Aa}$ \\
\hline BRS Rubissol & $30.03 \mathrm{Bab}$ & $66.50 \mathrm{Aa}$ & $41.22 \mathrm{Bab}$ & $85.41 \mathrm{Aa}$ \\
\hline Brazlândia Roxa & 22.99 Bab & $37.73 \mathrm{Ab}$ & $30.50 \mathrm{Bb}$ & $49.19 \mathrm{Ab}$ \\
\hline BRS Amélia & $22.54 \mathrm{Aab}$ & $34.81 \mathrm{Ab}$ & $26.94 \mathrm{Bb}$ & $78.36 \mathrm{Aa}$ \\
\hline Brazlândia Rosada & $11.63 \mathrm{Bb}$ & $28.55 \mathrm{Ab}$ & $18.84 \mathrm{Ab}$ & $37.20 \mathrm{Ab}$ \\
\hline
\end{tabular}

$\mathrm{MRN}$, marketable root number; TRN, total root number; RD, root diameter; MRW, mean root weight; MY, marketable yield; TY, total yield.

* Means within rows followed by different uppercase letters and means within columns followed by different lowercase letters are significantly different by Tukey's test $(p<0.05)$.

As shown in Table 3, Beauregard did not differ in marketable or total yield between growing seasons, and yields were higher than those of other clones in both seasons. BRS Amélia and Brazlândia Rosada showed similar marketable yields and total yields, respectively, in the two seasons. The yields obtained by Amaro et al. (2017) in 2013 with Beauregard (20.69 $\mathrm{t} \mathrm{ha}^{-1}$ ) and Brazlândia Roxa (24.62 $\mathrm{t} \mathrm{ha}^{-1}$ ) were similar to those observed here. In the study of Melo et al. (2020), although Beauregard and BRS Rubissol had a very high total root number, the clones afforded yields lower than those observed in the current study; Brazlândia Roxa and BRS Amélia had similar yields to those reported here.

The mean yield of sweet potato in Brazil was $14.06 \mathrm{t} \mathrm{ha}^{-1}$ in 2019 (IBGE, 2020), lower than that provided by Beauregard, BRS Amélia, Brazlândia Roxa, and BRS Rubissol in the current study. Brazlândia Rosada, however, afforded a similar yield in the 2017 season. This result indicates that farmers have not been using improved genotypes, leading to reduced yields and, consequently, lower profits.

Root length was not influenced by the interaction between clones and growing seasons (Table 4). Sweet potato genotypes developed longer roots in 2017/2018, and BRS Rubissol was the clone with the highest root length. Carmona et al. (2015), in assessing 23 sweet potato genotypes in Brasília, Federal District, found that Brazlândia Rosada had a root length of $15.40 \mathrm{~cm}$, which is within the ideal range of 12 to $16 \mathrm{~cm}$ proposed by Miranda et al. (1995). According to Miranda et al. (1995), root length is the first parameter used to discriminate between clones; the trait is useful for material selection and is associated with increased yield. This fact underscores the potential of BRS Rubissol, which had the highest root length, differing significantly from Brazlândia Rosada and Beauregard. 
Table 4. Mean root length of sweet potato according to growing season and clone. Curitibanos, Santa Catarina, Brazil.

\begin{tabular}{cc}
\hline Growing season & Root length $(\mathbf{c m})$ \\
\hline $2016 / 2017$ & $18.56 \mathrm{~B}$ \\
$2017 / 2018$ & $20.11 \mathrm{~A}$ \\
\hline Clone & Root length $(\mathbf{c m})$ \\
\hline Brazlândia Rosada & $17.09 \mathrm{~b}$ \\
BRS Rubissol & $22.38 \mathrm{a}$ \\
Brazlândia Roxa & $20.20 \mathrm{ab}$ \\
BRS Amélia & $18.89 \mathrm{ab}$ \\
Beauregard & $18.11 \mathrm{~b}$ \\
\hline
\end{tabular}

*Different uppercase letters indicate significant differences between growing seasons, and different lowercase letters indicate significant differences between clones (Tukey's test, $p<0.05$ ).

The environmental conditions of Curitibanos, Santa Catarina, in 2017/2018 favored total and marketable yield and total and marketable root number compared with the environmental conditions of 2016/2017. Such a difference in yield between growing seasons might be related to differences in rainfall. According to Silva et al. (2008), the water requirements of sweet potato ranges from 750 to $1000 \mathrm{~mm}$ during the cycle, and $500 \mathrm{~mm}$ are required during the growth phase, mainly for the development of tuberous roots. Stathers et al. (2005) stated that tuberous roots develop from the 9th week onward, necessitating a greater amount of water. Meteorological data (Figures 1 and 2) showed that, from the 9th week of cultivation until the time of harvest, there was a cumulative rainfall of $277 \mathrm{~mm}$ in 2016/2017 and $500.8 \mathrm{~mm}$ in 2017/2018.

BRS Rubissol and Beauregard were considered the most suitable for cultivation under the environmental conditions of Curitibanos, Santa Catarina. The clones are highly accepted by consumers because of their morphological characteristics and by farmers because of their high yields. BRS Rubissol has an intense purple skin and cream-colored pulp. It is widely used in industrial processing and for table consumption. Beauregard, on the other hand, has purplish-red skin and orange pulp. The clone draws the attention of consumers because of its high carotenoid content.

Interaction effects of genotypes and the environment are of considerable relevance in genetic improvement programs, particularly for initial selection and genotype recommendation (final phases). Genotypes that exhibit stable behavior over several growing seasons are preferred, particularly those that show superior performance (CRUZ et al., 2012; BORÉM et al., 2017). Sweet potato is known to adapt easily to different growing conditions, although productive performance may vary according to site and crop year (AMORIN et al., 2011; SILVA et al., 2015; AMARO et al., 2017; AMARO et al., 2019). Therefore, clone evaluation experiments are important for genotype recommendations, evidence of the relevance of the present study. Sweet potato is an important crop for small farmers in the Curitibanos region. The results of this study may help promote the use of improved genotypes, generating an increase in farmers' income and, ultimately, in the average national production.

\section{Conclusion}

Significant interaction effects between sweet potato clones and growing seasons were observed on root diameter, marketable root number, total root number, mean root weight, total yield, and marketable yield. Root length did not differ between growing seasons in the evaluated clones.

\section{References}

AMARO, G.B.; FERNANDES, F.R.; SILVA, G.O.; CASTRO, L.A.S. Desempenho de cultivares de batata doce na região do Alto ParanaíbaMG. Horticultura Brasileira, v.35, n.2, p.286-291, 2017. https://doi.org/10.1590/s0102-

$\underline{053620170221}$

AMARO, G.B.; TALAMINI, V.; FERNANDES, F.R.; SILVA, G.O.; MADEIRA, N.R. Desempenho de 
cultivares de batata-doce para rendimento e qualidade de raízes em Sergipe. Revista Brasileira de Ciências Agrárias, v.14, n.1, p.1-6, 2019. https://doi.org/10.5039/agraria.v14i1a5628

AMORIN, B. S. C.; OLIVEIRA, G.I.S.; SILVEIRA, M.A.; NASCIMENTO, I.R.; FERREIRA, T.A. Adaptabilidade fenotípica de genótipos de batata-doce oriundos de sementes botânicas na região Sul do Estado do Tocantins. Pesquisa Aplicada e Agrotecnologia, v.4, n.3, p.31-50, 2011. https://doi.org/10.5777/PAeT.V4.N3.02

BORÉM, A.; MIRANDO, G.V.; FRITCHE-NETO, R. Melhoramento de Plantas. 7. ed. Viçosa: UFV, 2017. 543 p.

BRASIL. Ministério da Agricultura, Pecuária e Abastecimento. Registro Nacional de Cultivares. Brasília: RNC, 2020. Disponível em: http://sistemas.agricultura.gov.br/snpc/cultivarw eb/cultivares registradas.php. Acesso em 19 mai. 2020.

CARMONA, P.A.O.; PEIXOTO, J.R.; AMARO, G.B.; MENDONÇA, M.A. Divergência genética entre acessos de batata-doce utilizando descritores morfoagronômicos das raízes. Horticultura Brasileira, v.33, n.2, p.241-250, 2015. https://doi.org/10.1590/S0102-

053620150000200017

CAVALCANTE, M.; FERREIRA, P.V.; PAIXÃO, S.L.; COSTA, J.G.; PEREIRA, R.G.; MADALENA, J.A.S. Potenciais produtivo e genético de clones de batata-doce. Acta Scientiarum Agronomy, v.31, n.3, p.421-426, 2009. https://doi.org/10.4025/actasciagron.v31i3.835

CRUZ, C.D. Programa Genes (Versão Windows): aplicativo computacional em Genética e Estatística. 1. ed. Viçosa: UFV, 2001. v. 1. 648 p.

CRUZ, C.D.; REGAZZI, A.J.; CARNEIRO, P.C.S. Modelos biométricos aplicados ao melhoramento genético. 4. ed. Viçosa: UFV, 2012. v. 1. 514 p.

EMBRAPA. Sistema Brasileiro de Classificação de Solos. 5. ed. Brasília: Embrapa, 2018. 355 p.

IBGE. Produção agrícola - lavoura temporária: 2019. 2020. Disponível em: https://cidades.ibge.gov.br/brasil/pesquisa/14/1 0233. Acesso em: 16 jun. 2021.

LEAL, M.H.S.; ZEIST, A.R.; RODRIGUES JÚNIOR, N.R.; SILVA JÚNIOR, A.D.; ARANTES, J.H.V.; GARCIA NETO, J.; PIERI, J.R.S.; PERRUD, A.C. Selection of new sweet potato genotypes based on production parameters, physical root characteristics and resistance to Euscepes postfasciatus. Journal of Crop Science and Biotechnology, v.24, p.349-360, 2021. https://doi.org/10.1007/s12892-020-00083-0

MASSAROTO, J.A.; MALUF, W.R.; GOMES, L.A.A.; FRANCO, H.D.; GASPARINO, C.F. Desempenho de clones de batata-doce. Ambiência, v.10, n.2, p.73-81, 2014. https://doi.org/10.5935/ambiencia.2014.01.06

MELO, R.A.C.; AMARO, G.B.; SILVA, G.O.; SANTOS, F.H.C.; VENDRAME, L.P.C. Root production and quality atributes of sweetpotato genotypes in Brasília-DF, Brazil, during two croping seasons. Colloquium Agrariae, v.15, n.2, p.90-95, 2020. https://doi.org/10.5747/ca.2019.v15.n6.a362

MIRANDA, J.E.C.; FRANÇA, F.H.; CARRIJO, O.A.; SOUZA, A.F.; PEREIRA, W.; LOPES, C.A.; SILVA, J.B.C. A cultura da batata-doce. 2. ed. Brasília: Embrapa Hortaliças, 1995. 94 p.

SILVA, J.B.C.; LOPES, C.A.; MAGALHÃES, J.S. Batata-doce (Ipomoea batatas). 6. ed. Brasília: Embrapa Hortaliças, 2008. 23 p.

SILVA, G.O.; SUINAGA, F.A.; PONIJALEKI, R.; AMARO, G.B. Desempenho de cultivares de batata-doce para caracteres relacionados com o rendimento de raiz. Revista Ceres, v.62, n.4, p.379-383, 2015. https://doi.org/10.1590/0034737X201562040007

STATHERS, T.; NAMANDA, S.; MWANGA, R.O.; KHISA, G.; KAPINGA, R. Manual for sweetpotato integrated production and pest management farmer field schools in sub-Saharan Africa. Uganda: International Potato Center, 2005. $168 \mathrm{p}$.

TANAKA, M.; ISHIGURO, K.; OKI, T.; OKUNO, S. Functional componentes in sweetpotato and their genetic improvement. Breeding Science, v.67, p.52-61, 2017. 
UFSC. Boletim anual - estação meteorológica sede UFSC Curitibanos. 2016. Disponível em: https://agriculturaconservacionista.ufsc.br/agro meteorologia/estacao-ufsccuritibanos /boletimanual ufsc 2016/. Acesso em: 26 jul. 2018.

UFSC. Boletim anual - estação meteorológica sede UFSC Curitibanos. 2017. Disponível em: https://agriculturaconservacionista.ufsc.br/agro meteorologia/estacao-ufsccuritibanos /boletimanual ufsc 2017-2/. Acesso em: 26 jul. 2018.

UFSC. Boletim anual - estação meteorológica sede UFSC Curitibanos. 2018. Disponível em: https://agriculturaconservacionista.ufsc.br/agro meteorologia/estacao-ufsccuritibanos /boletimanual ufsc 2018/. Acesso em: 26 jul. 2018.

YOSHIMOTO, M. Physiological functions and utilization of sweet potato. In: RAY, R.C.; TOMLINS, K.I. (Eds.). Sweet potato: post harvest aspects in food, feed and industry. New York: Nova Science Publishers, 2011. p. 59-89. 